\title{
MRI FOR DETERMINING RELATIONS BETWEEN THE SPIN DENSITY AND RELAXATION TIMES FOR STABILITY OF FREE INDUCTION DECAY SIGNAL
}

\author{
A. V. Netreba, V. S. Gavrilyuk \\ Taras Shevchenko National University of Kyiv, Department of Radiophysics, \\ 64, Volodymyrska St., Kyiv, UA-01033, Ukraine \\ e-mail:Vitabonbon@mail.ru \\ (Received by February 17, 2016; in final form May 16, 2016)
}

\begin{abstract}
We have studied the dependence of stability of the free induction decay signal on the time of the spin echo and the time of pulse sequence on real tomographic image. The reconstruction of images using direct and inverse Fourier transform has been carried out. We estimated the changing of characteristics of the restored images. The relations between the pulse sequence parameters time of the spin-echo TE and time of the pulse sequence TR have been set. We used a confidence interval for a full assessment of the accuracy of the calculation of the correlation coefficient compared to point evaluation. The creation of optimal conditions for a tomographic experiment, where TE and TR are set, signal stability provided, has been investigated.

Key words: Magnetic resonance imaging (MRI), weighted relaxation by $\rho, T_{1}$ and $T_{2}$, stability, FIDS, visualization.
\end{abstract}

PACS number(s): 87.61.-c, 87.19.1f

\section{INTRODUCTION}

A large number of instrumental methods of study are used in medicine. Some of them are universal. It allows to diagnose many different pathologies of human diseases of different classification groups. This is the MRI machine. It allows you to visualize the tissue without using radiation exposure. The current stage of development of medicine is characterized by the widespread introduction into clinical practice of more and more sophisticated methods of diagnosis. They not only facilitate the visualization of a pathological center but in some cases change our understanding about a particular feature of the different deseases [1]. MRI makes different soft tissues of the body contrast. This is especially useful for imaging the brain, muscles, heart and cancer, compared with other medical imaging techniques such as computed tomography (CT) or radiography.

There are various ways to improve the information content of MRI. Along with the reconstruction of the spatial distribution of spin relaxation characteristics the applied researches [2] for optimization of the reconstruction based on the diffusion weighting are widely conducted.

The intensity of the received signal depends on the parameters of tissues, including proton density $\rho$ and $T_{1}$, $T_{2}$ relaxation times, the parameters of TR and TE pulse sequence. In terms of MRI, weighed and proton density images $\rho$ were introduced. Depending on which option is weighed images contrast of tissues will be different. Weighed combination is possible in a survey of patients and may provide additional information [3]. The weighed images by $T_{1}, T_{2}$ and $\rho$ have a great potential and clinical significance for determining lesion and pathology in disorders of the brain, liver, meniscus, cartilage and other organs and tissues [4].

Previous studies in the reconstruction of magnetic res- onance (MR) images were used to restore the individual $T_{1}$ - or $T_{2^{-}}$weighed images. Different images are not really independent. They are images of the same section, and therefore are closely linked. Using the correlation between the images gives a better reconstruction. A significant improvement in the accuracy of restoration can be achieved by considering the correlation between different $T_{1^{-}}$and $T_{2}$-weighed objects [5].

Weighing by $T_{1}$ makes the highest intensity for fat, bone marrow and muscle tone of low intensity, water and collagen tissue. The weight to $T_{2}$ produces high-intensity muscle tone, water and collagen tissue and fat low intensity as the bone marrow. Images with time of the pulse sequence TR and time of the spin-echo TE, which enhances $T_{2}$ contrast, are called weighed images [6].

A lot of methods of processing of images are available and optimized for specific methods in diagnosing diseases. These results show that $T_{1}, \rho$ and $T_{2}$ may complement each other with the information about molecular environment by contrast enhancement [7]. The types of tissues have the same characteristics compared to the brain. This is important because the characteristics of the type of tissues, such as $T_{1}$, and $T_{2}$, relaxation and proton density may vary depending on the individual brain. Tissue classification of magnetic resonance images (MRI) of the brain protects against the intensity of inhomogeneity artifacts. The artifacts may hinder the automatic method for classification of tissues in MRI of the brain. The experiments confirm that the new method offers a useful improvement of tissue classification accuracy when the basic tissue characteristics vary across the brain and the noise level of the images is reasonable [8].

Major contrasts in MRI are based on differences in the density of water and oil, $T_{1}$, and $T_{2}$ from different tissues. The strongest signal is achieved with a long TR and a short TE [9]. Adding the contrast based on the difference in between $T_{2}$ is achieved by measuring the image 
signal in MR-TE, approximately equal to the average $T_{2}$ of the tissues of interest. The result is a weighed by $T_{2}$ image. $T_{1}$ and $T_{2}$ are combined rarely, because those objects remaining bright in $T_{1}$ image, are usually dark in $T_{2}$ weighed images and vice versa. Thus, the combination of these weighed images will result in an image where all tissues are dark [10].

The reconstruction of the magnetic resonance images weighed by relaxation times is based on the mathematical models of the dependence between experimentally estimated free induction decay signals FIDS and proton density distribution. The results described in [11] have a special significance for the diagnostics of illnesses caused by complex biochemical changes in tissues. Hence the obtained mathematical dependencies allow pulse parameters optimization and minimization of background tissue with maximal visualization of the region of interest (ROI) on MR images [12].

Today, the most widely used NMR imaging has become a tool of diagnosis, condition monitoring, process planning treatment, in-vivo spectroscopy, angiography, and others [13-15]. Most studies in this area in recent years are connected to the problems of the application of NMR imaging in medicine. The visualization problem is in the interpretation of imaging data, obtaining the connection between the parameters of the pulse sequence.
Knowing one parameter is required to define another. The problem, which has been solved in this work, aims at is creating optimal conditions for a tomographic experiment, where TE and TR are set proceeding from stability of signal of recession-free induction (FIDS).

\section{THE RESULTS OF THE STUDY}

The theory of stability developed by an outstanding Russian scientist O. M. Lyapunov studies the problem of the dependence of solutions of differential equations on initial conditions on semiaxis [16]. Function decline in free induction signal was investigated for stability:

$$
\begin{aligned}
& S\left(t_{1}, t_{2}\right)=\sum_{x, y} \rho(x, y) \times\left(1-\exp \left(-\frac{T R}{T_{1}(x, y)}\right)\right) \\
& \times \exp \left(-\frac{T E}{T_{2}(x, y)}\right) \times \exp \left(i \gamma\left(x G_{x} t_{1}+y G_{y} t_{2}\right)\right)
\end{aligned}
$$

Consider the equation

$$
\sum_{x, y} \rho(x, y) \times \exp \left(i \gamma\left(x G_{x} t_{1}+y G_{y} t_{2}\right)=A\right.
$$

where $A$ is constant. Then the expression takes the form:

$$
S\left(t_{1}, t_{2}\right)=A \times\left(1-\exp \left(-\frac{T R}{T_{1}(x, y)}\right)\right) \times \exp \left(-\frac{T E}{T_{2}(x, y)}\right) .
$$

A differential equation has been found:

$$
\begin{gathered}
\frac{d S}{d T R}=A \times\left(\frac{1}{T_{1}(x, y)} \times \exp \left(-\frac{T R}{T_{1}(x, y)}\right)\right) \times \exp \left(-\frac{T E}{T_{2}(x, y)}\right), \\
\frac{d S}{d T E}=A \times\left(1-\exp \left(-\frac{T R}{T_{1}(x, y)}\right)\right) \times-\frac{1}{T_{2}(x, y)} \exp \left(-\frac{T E}{T_{2}(x, y)}\right) .
\end{gathered}
$$

Investigating the Lyapunov stability, we find equations (1) and (2):

$$
\begin{gathered}
\frac{d T E}{d T R}=\frac{A \times\left(\frac{1}{T_{1}(x, y)} \times \exp \left(-\frac{T R}{T_{1}(x, y)}\right) \times\left(\exp \left(-\frac{T E}{T_{2}(x, y)}\right)\right)\right.}{A \times\left(1-\exp \left(-\frac{T R}{T_{1}(x, y)}\right)\right) \times\left(-\frac{1}{T_{2}(x, y)} \times \exp \left(-\frac{T E}{T_{2}(x, y)}\right)\right)} \\
=\frac{-T_{2}(x, y)}{T_{1}(x, y) \times\left(\exp \left(\frac{T R}{T_{1}(x, y)}\right)-1\right)}=\frac{T_{2}(x, y)}{T_{1}(x, y) \times\left(1-\exp \left(\frac{T R}{T_{1}(x, y)}\right)\right)} .
\end{gathered}
$$

Having integrated the obtained equation (2) by the TR function we obtain a dependence function of the spin-echo TE on the time of the pulse sequence TR:

$$
T E(T R)=\frac{T_{2}(x, y)}{T_{1}(x, y)} \times T R-T_{2}(x, y) \times \ln \left(\exp \left(\frac{T R}{T_{1}(x, y)}\right)-1\right)
$$


So, the solution of the FIDS function is stable throughout the defined area $(0,+\infty)$. For the signal to remain stable with an increasing duration of the pulse sequence the time of the spin echo must be reduced. Using tabulated values for tissue $T_{1}$ and $T_{2}$ relaxation [9] and formula (2) dependence (1) was obtained.

The reconstruction of tomograms by direct and inverse Fourier transform has been program-implemented for white tissue 2 and gray tissue 3 .

The changing of the characteristics of the restored images using correlation coefficient and represented as a dependence of the coefficient on the ratio of time spin echo pulse sequence to the time of (4) and (5). As shown in the graph, the smaller the ratio of TE to TR, the greater the correlation coefficient. The following formula was used for finding the correlation:

$$
k=\frac{\sum_{i=0}^{255} \sum_{j=0}^{255}\left(x_{i, j}-\bar{x}\right) \times\left(y_{i, j}-\bar{y}\right)}{\sqrt{\sum_{i=0}^{255} \sum_{j=0}^{255}\left(x_{i, j}-\bar{x}\right)^{2} \times \sum_{i=0}^{255} \sum_{j=0}^{255}\left(y_{i, j}-\bar{y}\right)}}
$$

where $k$ is the coefficient of correlation; $x_{i, j}$ is the brightness of each pixel of the original images; $y_{i, j}$ is the brightness of each pixel of the reconstructed image; $\bar{x}$ is the average brightness value of a pixel of the original image; $\bar{y}$ is the average pixel brightness of the reconstructed image.

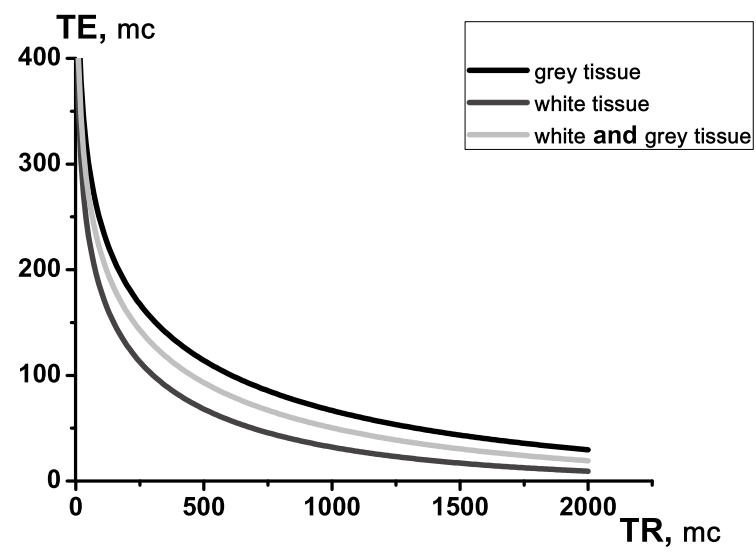

Fig. 1. The dependence of time of the spin echo on the time of the pulse sequence for white and grey tissues.

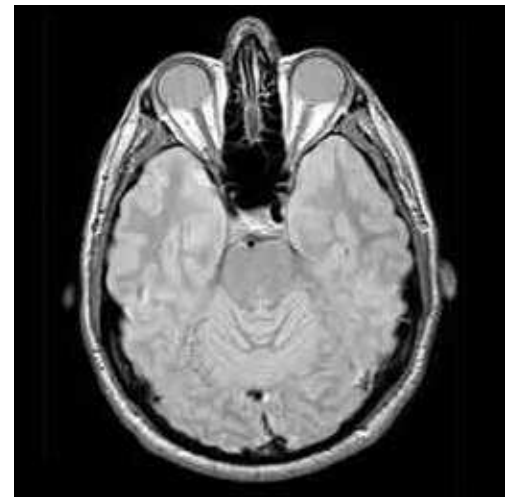

a)

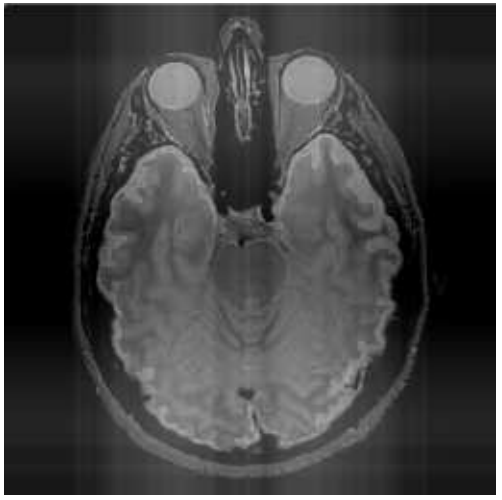

b)

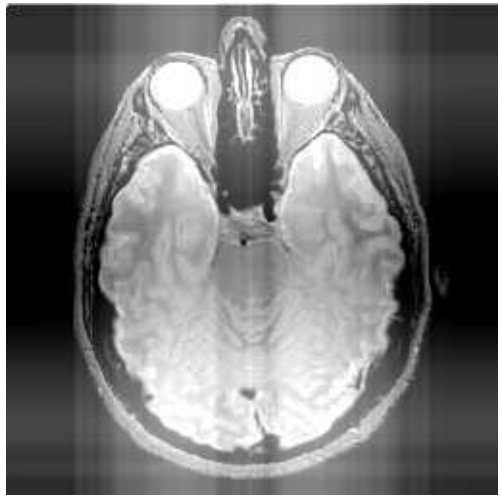

c)

Fig. 2. Scan image of cerebrum on proton density-weighed (a), reconstructed images at $\mathrm{TR}=900 \mathrm{~ms}$ and $\mathrm{TE}=37 \mathrm{~ms}(\mathrm{~b})$ reconstructed image at $\mathrm{TR}=1600 \mathrm{~ms}$ and $\mathrm{TE}=15 \mathrm{~ms}$ (c) for white tissue.

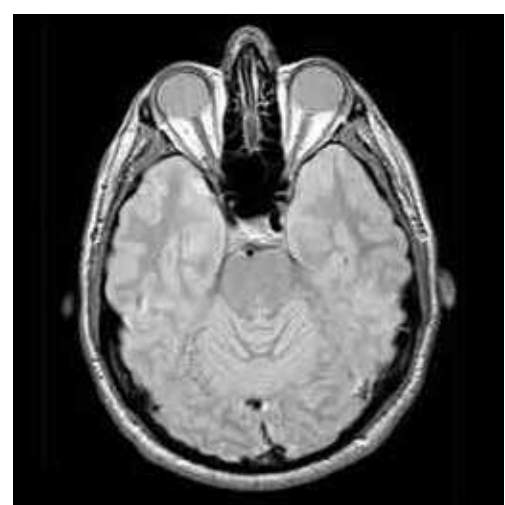

a)

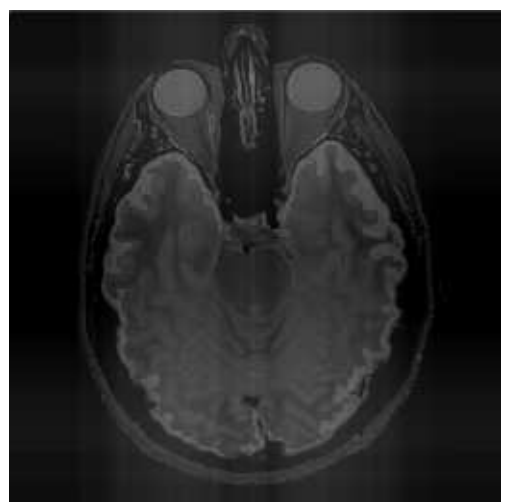

b)

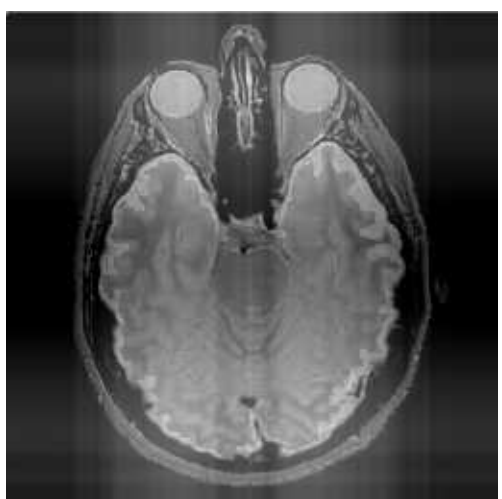

c)

Fig. 3. Scan image of cerebrum on proton density-weighted (a), reconstructed images at $\mathrm{TR}=900 \mathrm{~ms}$ and $\mathrm{TE}=74 \mathrm{~ms}(\mathrm{~b})$ reconstructed image at $\mathrm{TR}=1600 \mathrm{~ms}$ and $\mathrm{TE}=40 \mathrm{~ms}(\mathrm{c})$ for grey tissue. 


\begin{tabular}{|c|c|c|}
\hline $\mathbf{N}$ & $\mathbf{T E} / \mathbf{T R}$ & $\mathbf{k}$ \\
\hline 1 & 0.041 & 0.787 \\
\hline 2 & 0.032 & 0.790 \\
\hline 3 & 0.021 & 0.793 \\
\hline 4 & 0.014 & 0.796 \\
\hline 5 & 0.009 & 0.799 \\
\hline
\end{tabular}

Table 1. The values of coefficient of correlation and the ratio of the time of the spin echo pulse sequence for white tissue.

\begin{tabular}{|c|c|c|}
\hline $\mathbf{N}$ & $\mathbf{T E} / \mathbf{T R}$ & $\mathbf{k}$ \\
\hline 1 & 0.082 & 0.777 \\
\hline 2 & 0.068 & 0.779 \\
\hline 3 & 0.047 & 0.783 \\
\hline 4 & 0.034 & 0.786 \\
\hline 5 & 0.025 & 0.789 \\
\hline
\end{tabular}

Table 2. The values of coefficient of correlation and the ratio of the time of the spin echo pulse sequence for grey tissue.

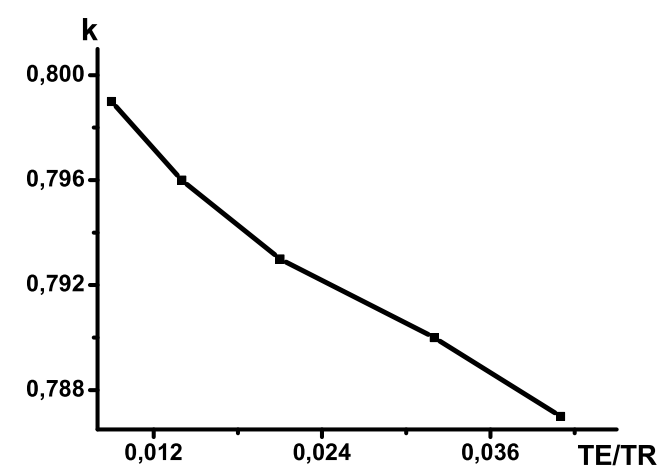

Fig. 4. The dependence of the correlation coefficient on the ratio of the time of the spin echo pulse sequence for white tissue.

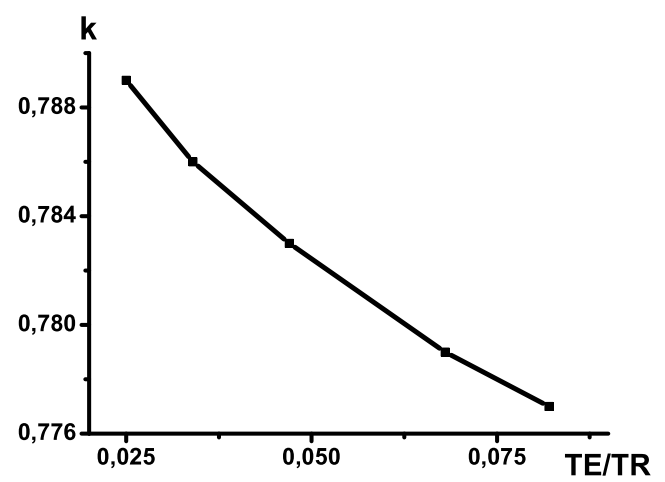

Fig. 5. The dependence of the correlation coefficient on the ratio of the time of the spin echo pulse sequence for grey tissue.
The similarity of the reconstructed images was evaluated using the correlation coefficient. The lower the ratio TE/TR, the greater the correlation coefficient. For a complete understanding about the accuracy of the correlation coefficient and reliability of assessment of random variation of calculating the confidence interval for the correlation coefficient [17]:

$$
\left(k-t_{\text {critical }} \times \frac{1-k^{2}}{\sqrt{n}}, k+t_{\text {critical }} \times \frac{1-k^{2}}{\sqrt{n}}\right)
$$

$t_{\text {critical }}=(d ; \alpha)=1.96$ is the critical values of the Student; $\alpha=0.05$ being the level of importance; $d=n-2$ is the degree of freedom; $t_{\text {critical }}$ is the critical values of the Student; $n=256 \times 256=65536$.

\begin{tabular}{|c|c|c|c|}
\hline $\mathbf{N}$ & $\mathbf{T E} / \mathbf{T R}$ & $\mathbf{k}$ & confidence interval \\
\hline 1 & 0.168 & 0.763 & $0.7598-0.7662$ \\
\hline 2 & 0.082 & 0.777 & $0.7739-0.7801$ \\
\hline 3 & 0.047 & 0.783 & $0.7804-0.7859$ \\
\hline 4 & 0.025 & 0.789 & $0.7861-0.7919$ \\
\hline 5 & 0.015 & 0.804 & $0.8013-0.8067$ \\
\hline
\end{tabular}

Table 3. The values of the correlation coefficient, of the confidence interval and the ratio of times of spin-echo and pulse sequence for gray tissue.

\begin{tabular}{|c|c|c|c|}
\hline $\mathbf{N}$ & $\mathbf{T E} / \mathbf{T R}$ & $\mathbf{k}$ & confidence interval \\
\hline 1 & 0.097 & 0.768 & $0.7649-0.7711$ \\
\hline 2 & 0.041 & 0.787 & $0.7841-0.7899$ \\
\hline 3 & 0.021 & 0.793 & $0.7902-0.7958$ \\
\hline 4 & 0.009 & 0.799 & $0.7962-0.8018$ \\
\hline 5 & 0.005 & 0.806 & $0.8033-0.8087$ \\
\hline
\end{tabular}

Table 4. The values of correlation coefficient, of the confidence interval and the ratio of times of spin-echo and pulse sequence for white tissue.

A correlation coefficient is a coefficient that illustrates a quantitative measure of some type of correlation and dependence. The obtained values of the confidence interval show that correlation coefficient is in the confidence interval $\pm 5 \%$. The top and bottom line of random errors have been estimated, which are in confidence probability of $95 \%$.

\section{CONCLUSIONS}

The dependence of the time of spin echo on the time of the pulse sequence TR time under the conditions of stability FIDS has been received in formula (4). The function is not stable only at zero point. The obtained dependence allows to determine the time of spin-echo if the time of pulse sequence is known. The intensity of obtained signal depends on the parameters of tissues, in particular proton density, relaxation times $T_{1}$ and $T_{2}$ and on parameters TR and TE of pulse sequence. Depending on chosen parameters TR and TE the image may be weighed by $T_{1}, T_{2}$ or proton density $\rho$. Such an image contains the additional information. The 
pathology and correct diagnosis may be determined with the help of this method. The reconstruction for different parameters of times of pulse sequence have been carried out. The changing of the characteristics of the restored images with the help of correlation coefficient for tomograms, which increases with decreasing ratio TE / TR, has been estimated. The changing of ratio TE/TR from 0.041 to 0.009 leads to the changing of correlation coefficient from 0.787 to 0.799 for white tissue. For gray tissue the changing of ratio TE/TR from 0.082 to 0.025 leads to the changing of correlation coefficient from 0.777 to 0.789 . It has been found that the most optimal value of the ratio TE/TR equals to 0.02 for white matter and 0.05 for gray matter. These values correspond to the middle of the curve. With these values the condition of stability of the free induction signal recession is fulfilled. The confidence interval has been estimated for a full assessment of the correlation coefficient competing to point estimate. The results showed that at the most optimum value of the ratio $\mathrm{TE} / \mathrm{TR}=0.047$ and if $k=0.783$, the confidence interval is in the range of 0.780 to 0.786 with the probability of $95 \%$ for gray fabric. For the most optimal value of the ratio $\mathrm{TE} / \mathrm{TR}=0.021$ and if $k=0.793$, the confidence interval is in the range of 0.790 to 0.796 with the probability of $95 \%$ for white fabric. If the confidence intervals overlap for neighboring points, the step between adjacent points should be larger. Thus, a new method has been developed for the study of the optimal conditions for a tomographic experiment where TE and TR are set for stability conditions alarm. A change of one parameter does not significantly affect the reconstruction of tomograms, which is confirmed by the obtained results.
[1] O. Y. Zhelezniakov, Modern methods of medical imaging of benign tumors and tumor-like formations of ovarian diseases that mimic them (Kharkiv State Medical University, Kharkiv, 2004).

[2] O. Naguliak, A. V. Netreba, J. Phys. Stud. 19, 4 (2015).

[3] K. Kvistad, J. Rydland, J. Vainio, Radiology 216, 545 (2000).

[4] C. Mills, L. Crooks, L. Kaufman, M. Brant-Zawadzki, Radiology 150, 87 (1984).

[5] A. Majumdar, R. K. Ward, Magn. Reson. Imaging 29, 899 (2011).

[6] E. Lange, J. Mugler, J. Bosworth, Radiology 190, 727 (1994).

[7] C. Taylor, J. Carballido-Gamio, S. Majumdar, X. Li, Magn. Reson. Imaging 27, 779 (2009).

[8] J. Tohka, I. D. Dinov, D. W. Shattuck, A. W. Toga, Magn. Reson. Imaging 28, 557 (2010).

[9] M. Y. Marusina, A. O. Kaznacheeva, Sovremennye vidy tomografii [Modern Types Tomography] (SPbGU ITMO, Saint Petersburg, 2006).

[10] J. G. Pipe, Barrow Quart. 16, 1 (2000).
[11] A. Netreba, T. Pershina, S. Radchenko, in IEEE 34th International Scientific Conference on Electronics and Nanotechnology, ELNANO 2014 - Conference Proceedings, 2014, p. 310.

[12] A. Netreba, S. Radchenko, M. Razdabara, in IEEE 34th International Scientific Conference on Electronics and Nanotechnology, ELNANO 2014 - Conference Proceedings, 2014, p. 365.

[13] V. Positano, B. Salani, A. Pepe, M. F. Santarell, Magn. Reson. Imaging 27, 188 (2009).

[14] E. M. Haacke, N. Y. Cheng, M. J. House, Q. Liu, Magn. Reson. Imaging 23, 1 (2005).

[15] K. Yoshimitsu, Y. Nishihara, D. Okamoto, Y. Ushijima, Magn. Reson. Imaging 30, 854 (2012).

[16] S. Krivosheya, N. Mayko, A. Sugakova, Dyferencialni rivnjannja [Differential Equations] (Kyiv University Press, Kyiv, 2010).

[17] P. Senio, Teorija imovirnostej ta matematychna statystyka [Theory of Probability and Mathematical Statistics] (Znannja, Kyiv, 2007).

\title{
МАГНІТНО-РЕЗОНАНСНА ВІЗУАЛІЗАЦІЯ ДЛЯ ВИЗНАЧЕННЯ ЗВ'ЯЗКІВ МІЖ СПІНОВОЮ ГУСТИНОЮ ТА РЕЛАКСАЦЙНИМИ ЧАСОВИМИ ХАРАКТЕРИСТИКАМИ ЗА УМОВ СТІЙКОСТІ СИІНАЛУ СПАДУ ВІЛЬНОї ІНДУКЦІї
}

\author{
В. С. Гаврилюк, А. В. Нетреба \\ Київсъкий національний університет імені Тараса Шевченка, \\ факультет радіофізики, електроніки та комп'ютерних систем, вул. Володимирсъка, 64, 01033, Київ
}

Досліджено стійкість сигналу спаду вільної індукції (CCBI) залежно від часу спінового відлуння і часу імпульсної послідовності для реального томографічного зображення. Реалізовано реконструкцію зображень за допомогою прямого й оберненого перетворення Фур'є та оцінено зміну характеристик відновлених зображень. Встановлено зв'язки між значеннями часових параметрів імпульсної послідовності - часу спінового відлуння TE та часу імпульсної послідовності TR. Визначено довірчій інтервал для повної оцінки точності розрахунку коефіцієнта кореляції відновлених розподілів порівняно з точковою оцінкою. За заданих значень часових параметрів TE та TR досліджено оптимальні умови проведення томографічного експерименту, які забезпечують стійкість вимірюваного сигналу. 